\title{
Research on the Application of Neuromarketing Technologies on Financial Markets
}

\author{
Svetlana V. Karpova ${ }^{1}$, Ilya V. Rozhkov ${ }^{2}$ \\ Department of Management \\ Financial University under the Government of the Russian Federation \\ ${ }^{1}$ SVKarpova@fa.ru, ${ }^{2}$ irojkov@fa.ru
}

\begin{abstract}
The change in marketing paradigms, which occurs under the influence of the rapid development of information technologies and new forms of communication, requires the search for more objective methods of consumer research. Neuroeconomics and neuromarketing as its applied branch allow to study psychophysical states of a person in the process of consumer choice. The article attempts to identify the most promising areas of application of neuromarketing technologies. The review of the most significant directions in Russia and abroad is carried out. Possible prospective directions for the development of neuromarketing research on the financial market are identified: machine learning, social scoring, artificial neural networks.
\end{abstract}

Key words: neuroeconomics, neuromarketing, machine learning, social scoring, artificial intelligence.

\section{PROBLEM STATEMENT}

For more than a century of studying marketing as a methodology and a philosophy of market activity went through several stages of development. The change in the marketing paradigms, characteristic of certain periods of socio-economic relations development throughout the 20th century is a consequence of the fundamental changes that took place in society during this period. Each subsequent stage moved the vector in the marketing activities of organizations from the intra-organizational environment to consumers, their needs and necessities, as well as the sustainable development of society as a whole [3].

Within the framework of modern marketing and marketing concepts 3.0 and 4.0, consumers are perceived as "full-fledged human beings endowed with thoughts, emotions, and soul" [4]. P. Kotler notes that a person in the modern world not only meets his needs and desires, but seeks to make our modern globalized world better or, at least, not to harm the society and nature. Thus, consumers not only get satisfaction from their functional, but also from emotional needs. The basis for such selfrealization of consumers is formed by the possibilities of modern information technologies and digital-marketing as social networks, mobile devices for transferring information, new forms of collective interaction of people on the basis of information services.

With the growth of technical capabilities of communication and interaction of people, the question of improving existing and searching for new technologies for consumer research is being updated. Such technologies can provide deep and qualitative study of behavioral patterns, mental insights, psychological and emotional state of a person in order to improve the efficiency of market activities. Particularly important is the study of factors of increasing consumers' involvement in interaction with the company, communication with its brand and products, participation in the joint development of new products (co-marketing) and their promotion on the market (viral marketing). The most promising methodology for this kind of research is neuromarketing, it is a section of a more general scientific area of neuroeconomics, which object of research is consumer behavior.

At present, neuroeconomics is increasingly attracting the attention of Russian and foreign scientists and is becoming a long-term priority of scientific research. According to the estimates of the NeuroNet branch association, engaged in the development and promotion of neurotechnologies in Russia, the market for neuroscientific research will reach $\$ 100$ billion by 2020 and 1.8 trillion by 2035 [6]. Prospects for the use of neurotechnologies are also taken into account at the state level in the long-term planning of the development of the digital economy in the Russian Federation. So, according to the program "Digital Economy of the Russian Federation" No. 1632-r dated July 28, 2017, the main end-to-end digital technology is "neurotechnology and artificial intelligence" [1]. In this connection, it is of particular interest to analyze the current state and prospects for the development of Russian and international neuromarketing research markets. Its results can serve as the basis for the formation of foresight of applied and fundamental research, not only to solve the problems of promoting the products of domestic producers, but also to increase its competitiveness by taking into account the needs of consumers more deeply.

\section{BACKGROUND REVIEW}

In general, the concept of neuromarketing was first developed by Harvard University psychologists in the 1990s. The technology is based on the model according to which the bulk (more than 90\%) of human thought activity, including emotions, occurs in the subconscious area, that is, below the levels of controlled awareness.

Neuroeconomics or neurobiology of decision-making is an interdisciplinary field at the intersection of psychology, biology 
and behavioral economics. Currently, neurotechnologies are used in various applied fields: medicine (neurophysiology and neurotechnology), transport and logistics, industrial sphere, information technologies, etc. The most significant studies in the field of neuromarketing are presented in Table 1.

\section{Table 1}

Analysis of the most significant foreign studies in the field of neuromarketing

\begin{tabular}{|c|c|c|c|}
\hline Country & Scientists & Research Center & $\begin{array}{l}\begin{array}{l}\text { Directions } \\
\text { research }\end{array} \\
\end{array}$ \\
\hline $\begin{array}{l}\text { United } \\
\text { Kingdom }\end{array}$ & $\begin{array}{l}\text { Roman } \\
\text { Borisyuk }\end{array}$ & $\begin{array}{l}\text { University of } \\
\text { Plymouth }\end{array}$ & $\begin{array}{l}\text { Biological } \\
\text { realistic models } \\
\text { of the formation } \\
\text { of neuro- } \\
\text { architectures and } \\
\text { functions }\end{array}$ \\
\hline Netherlands & $\begin{array}{l}\text { Ale } \\
\text { Schmits }\end{array}$ & $\begin{array}{ll}\text { University } & \text { of } \\
\text { Erasmus } & \text { of } \\
\text { Rotterdam } & \end{array}$ & Neuromarketing \\
\hline USA & $\begin{array}{l}\text { Gregory } \\
\text { Burns }\end{array}$ & Emory University & $\begin{array}{l}\text { Consumer } \\
\text { behavior }\end{array}$ \\
\hline USA & $\begin{array}{l}\text { Brian } \\
\text { Knutson, } \\
\text { Alexander } \\
\text { Geneva } \\
\end{array}$ & $\begin{array}{l}\text { Stanford } \\
\text { University }\end{array}$ & Neuroprediction \\
\hline France & $\begin{array}{l}\text { Hilke } \\
\text { Plassmann }\end{array}$ & INSEAD & Neuroprediction \\
\hline USA & $\begin{array}{l}\text { Vernon } \\
\text { Smith }\end{array}$ & $\begin{array}{l}\text { Center for } \\
\text { Neuroeconomics } \\
\text { Studies }\end{array}$ & $\begin{array}{l}\text { Experimental } \\
\text { Economics }\end{array}$ \\
\hline Germany & $\begin{array}{l}\text { Berndt } \\
\text { Weber }\end{array}$ & Bonn University & $\begin{array}{l}\text { Visual } \\
\text { communication }\end{array}$ \\
\hline USA, Israel & $\begin{array}{l}\text { Daniel } \\
\text { Kahneman } \\
\end{array}$ & $\begin{array}{l}\text { Princeton } \\
\text { University }\end{array}$ & $\begin{array}{l}\text { Behavioral } \\
\text { finance }\end{array}$ \\
\hline USA & $\begin{array}{l}\text { Jerry } \\
\text { Saltman }\end{array}$ & $\begin{array}{l}\text { Harvard Business } \\
\text { School }\end{array}$ & Neuromarketing \\
\hline
\end{tabular}

Without the use of neurotechnologies, the development of the following technologies couldn't be completed:

- artificial intelligence;

- virtual and augmented reality;

- search engines (neurocompliments);

- communications;

- assessment of physical, emotional and intellectual states of a person;

- Neuro-linguistic programming.

In the framework of neuroeconomical researches, scientists distinguish neuromarketing, which is a complex of methods for studying the behavior of consumers, the impact on it, as well as emotional and behavioral reactions to this impact, using the latest developments in the fields of marketing, cognitive psychology and neurophysiology [2].

Unlike traditional marketing methods, neuromarketing does not use subjective data to obtain information about consumer preferences. Neuromarketing allows you to influence the thoughts of a person before he has realized them and developed his position. The data obtained as a result of the analysis are most often used for:

- $\quad$ testing concepts and ideas for new products;

- $\quad$ testing of adverts and communications;

- $\quad$ testing of package and brand identification;

- $\quad$ studying the image and reputation of the organization;
- testing of sites' usability and interfaces;

- $\quad$ study of merchandising, work of trade and office space, efficiency of POS.

In Russia, a lot of scientific centers are engaged in neuroscience issues (Table 2).

Table 2

Russian research centers in the field of neuroscientific research

\begin{tabular}{|l|l|}
\hline Research Center & Directions of research \\
\hline $\begin{array}{l}\text { I. Kant Baltic Federal University, } \\
\text { Institute of Living Systems }\end{array}$ & $\begin{array}{l}\text { Genetically } \\
\text { technologies, nanomaterials, } \\
\text { applied engineering technologies, } \\
\text { etc. }\end{array}$ \\
\hline $\begin{array}{l}\text { Lomonosov Moscow State } \\
\text { University, laboratory of } \\
\text { neurophysiology } \\
\text { neurocomputer interfaces of the } \\
\text { Faculty of Biology }\end{array}$ & $\begin{array}{l}\text { Development of human-machine } \\
\text { interface technologies }\end{array}$ \\
\hline Kurchatov Institute SRC & $\begin{array}{l}\text { Neurotechnology of intelligent } \\
\text { information processing in real } \\
\text { time }\end{array}$ \\
\hline Pavlov Institute of Physiology & $\begin{array}{l}\text { Processing of image and sound } \\
\text { signals in the context of } \\
\text { neurotechnology }\end{array}$ \\
\hline $\begin{array}{l}\text { University ITMO, branch union } \\
\text { "NeuroNet" }\end{array}$ & $\begin{array}{l}\text { Technologies related to the } \\
\text { integration of the human brain and } \\
\text { computer }\end{array}$ \\
\hline
\end{tabular}

\section{THEORETICAL GROUNDING AND METHODOLOGY}

The most famous neuromarketing technology was developed by Harvard professor Jerry Saltman, who patented it as the Zaltman metaphor extraction method (ZMET).

The model is tested by the largest brands: Coca-Cola, Toyota, PNC, Proctor \& Gambel, General Motors, etc. Its main goal is to bring to the realized level the hidden thoughts of customers that continuously occur in their brains. They are able to evoke an emotional positive response and activate hidden requests that stimulate purchase.

The instrumental approach in neuromarketing is associated with the use of special equipment:

- $\quad$ Mobile Eye-tracking (mobile tracker);

- Polygraph / lie detector (for instrumental psychophysiological studies for synchronous recording of parameters of breathing, cardiovascular activity, electrical resistance of the skin, etc.);

- Stationary Eye-tracker (eye tracking technology);

- $\quad$ eye-tracker + audit of a site (the Webvisor in Yandex.Metric, the technology of recording and analizing of actions of visitors on a site);

- $\quad$ Face-reading (mobile laboratory testing the effectiveness of advertising);

- $\quad$ EEG and neurocomputer interface based on electroencephalography (systems for registration electroencephalograms helping to determine the brain's response to certain stimuli);

- MRI scanners (functional magnetic resonance tomography). 


\section{EMPIRICAL ANALYSIS}

Currently, among the practical areas of application of neuromarketing researches in the financial market, we can distinguish the following:

- artificial intelligence and machine learning;

- social scoring;

- artificial neural networks.

\section{Artificial intelligence and machine learning}

The prospects for neuro forecasting in the stock market are quite promising. Thus, the Cindicator service is a decentralized, community-driven technology infrastructure that enables the use of the values of hybrid artificial intelligence on the securities market, investment and crypto-currency markets. This synergy allows to make more precised decisions in the face of increasing uncertainty.

Cindicator is a mobile application in which users answer questions about how much companies' stocks or other financial instruments will cost in the nearest future. After that, the answers are aggregated and processed with the help of artificial intelligence, which forms a single forecast. The robot commits transactions based on the forecast on the stock exchange, and part of the profit from the trade is distributed among users. As a result, all participants become not only users, but also contributors, and their internal mental work becomes capital that can be effectively used. Over the past six months, the value of the company's portfolio has increased by $168 \%$, and the users of the mobile application have received dividends worth more than 24 thousands of dollars.

The Russian service of predictive analytics for the financial and cryptocurrencies market Cindicator has collected $\$ 15$ million in the cryptocurrency based on the initial placement of tokens (ICO).

To promote this startup a number of marketing tools was used. For example, most Russians learned about the project from the video on YouTube and from articles in magazines. Also, various conferences, meetings and other public events were held.

\section{Marketing tools based on social scoring}

One of the directions for implementing neurotechnologies based on Big Data is the integration of information about consumers from different sources. This technology is called "social scoring", which implies the collection of information about a client of a financial institution judging by his actions in social networks and data located in his accounts. Currently, there are several services using the technology of social scoring on the financial market. For example, the Double Data service is a solution for retail banks to improve the efficiency on all stages of working with individuals: from attracting customers and evaluating them to the collection of overdue debts due to the use of Big Data technologies, advanced machine learning techniques and data mining. Double Data collects information from open sources and includes them in existing models for evaluating potential customers, which, according to the product developers, allows to increase the efficiency of models by 10 $15 \%$ and reduces the number of non-performing loans. This service has already received more than 200 million rubles. investments from the funds of LETA Capital and Simile Venture Partners and is preparing to enter the markets of Europe, Asia and South America.

Social networks have also joined the development of social scoring technologies. Thus, Facebook has officially patented the program for sharing information with banks. From now on, credit institutions will be able to assess its creditworthiness with the help of a potential borrower profile in a social network. A new system (and in fact scoring on the Facebook social network) will tell banks about the borrower's friends in the social network. The more the borrower has friends with a good credit history, the higher the chances of getting a loan.

\section{Marketing tools based on artificial neural networks}

Neural network technologies are a set of information technologies based on the use of artificial neural networks. Artificial neural networks are software or hardware implemented systems built on the principle of organization and functioning of their biological analogue (the human nervous system).

FscoreLab is a tool developed by the Russian entrepreneur from St. Petersburg, Nikita Valeev, in 2017. It allows us to assess the creditworthiness of potential customers using neural network technologies on their photos and other parameters taken from social networks VKontakte, Odnoklassniki, Facebook. The service uses a neural network, trained on 600 thousand real cases of loan payment taken from the bases of the bureau of credit histories. The program examined photographs of people with arrears on loans and without it and independently identified the features intrinsic to the persons with debts. The service is planned to be monetized with the help of turnkey scoring projects for the largest banks (box solutions according to banks).

Currently, only 3.8 million rubles have been invested in the project. However, the startup has implemented five successful projects, which allowed to recoup investments and ten projects are in progress now. FscoreLab is present in Russia, Greece and the USA.

The cases examined indicate the prospects for the development of Russian marketing services based on neurotechnologies that will allow to design more sophisticated financial products that better meet the needs of the target audience and strengthen the Russian financial system.

\section{REFERENCES}

[1] Распоряжение Правительства РФ от 28.07.2017 N 1632-р «Об утверждении программы "Цифровая экономика Российской Федерации"» [The order of the Government of the Russian Federation of July 28, 2017 No. 1632-r "The Digital Economy of the Russian Federation"]. URL: http://www.consultant.ru/document/cons_doc_LAW_221756/.

[2] Маркетинговые коммуникации: учебник и практикум для прикладного бакалавриата / С Азарова и др.; Под ред О.Н. Жильцовой М.: Юрайт, 2014. -[Marketing communications: textbook and practical work for applied bachelor's degree / S. Azarova et al.; ed O. N. Zhiltsova. Moscow: Yurajt, 2014]. 
[3] Инновационный маркетинг / Под ред. Е.В. Карповой. М.: Юрайт, 2017. [Innovative marketing: a textbook for undergraduate and graduate programs / Ed. S.V. Karpova. Moscow: Yurajt, 2017.

[4] Kotler P., Kartajaya H., Setiawan I. Marketing 3.0: From Products to Customers to the Human Spirit. Hoboken: John Wiley and Sons, 2011 .
[5] Рожков И.В. Информационные системы и технологии в маркетинге. М.: Русайнс, 2014. [Rozhkov I.V. Information systems and technologies in marketing. Moscow: Rusains, 2014]. [6] NeuroNet. URL: http://rusneuro.net 